\section{The Effects of Public Debt on \\ Economic Growth in Sri Lanka \\ The Effects of Public Debt on}

Madhuhansi, W.G.C. ${ }^{1, *}$ and Shantha, A.A. ${ }^{2}$

1,2 Department of Economics and Statistics, Sabaragamuwa University of Sri Lanka, Belihuloya, 70140, Sri Lanka.
Sri Lanka Journal of Social Sciences and Humanities Volume 1 Issue 1, February 2021: 33-41 ISSN: 2773 692X (Online), 27736911 (Print) Copyright: (C) 2021 The Author(s)

Published by Faculty of Social Sciences and Languages, Sabaragamuwa University of Sri Lanka Website: https://www.sab.ac.lk/sljssh

Received: 03 November, 2020, Revised: 07 January, 2021, Accepted: 30 January, 2021.

How to Cite this Article: Madhuhansi, W.G.C., \& Shantha, A.A. (2021). The effects of public debt on economic growth in Sri Lanka. Sri Lanka Journal of Social Sciences and Humanities, 1(1), 33-41.

\begin{abstract}
The substantial literature has observed the relationship between public debt and economic growth in different countries and the performances of public debt on economic growth differed from country to country. Therefore, it is essential to have unique researches for each country. Hence, this study aims to identify the relationship between public debt and economic growth in Sri Lanka using four decades' latest data. This was examined using econometrics techniques and annual time series data from 1980 to 2019 aiming to fulfill the objective of the effects of public debt on economic growth in Sri Lanka. The Jacque Bera (JB) and Augmented Dickey-Fuller (ADF) tests are used to investigate the properties of the macroeconomic time series of normality and unit-roots respectively. The Engel-Ganger residual-based model used to investigate the long-run relationship between variables and the shortrun relationship of variables investigated using the Error Correlation Model (ECM). The study shows that both public domestic debt and public external debt have expanded in Sri Lanka in the studying period. Further, public external debt became closer to the public domestic debt during that period. Public domestic debt, public external debt, and public debt servicing have a negative and significant relationship with economic growth. Domestic debt has a powerful adverse effect on economic growth in the long run with comparing external debt. Further, the negative effect of external debt is stronger than domestic debt on economic growth in the short run. This study recommends that the Sri Lankan government needs to have some limitations regarding the level of borrowing due to adverse effects on economic growth and effective usage of public debt is essential for Sri Lanka.
\end{abstract}

Keywords: Economic growth, Public debt servicing, Public domestic debt, Public external debt

\section{INTRODUCTION}

Economies of all countries require a level of capital to generate production and to achieve sustainable economic development. In such a situation, when government spending is higher than its tax collection, it occurs budget deficit (Lee and $\mathrm{Ng}$, 2015). The government can expand its revenue by printing money, increasing taxes, using previous budget surplus and domestic or/and external borrowing. When the government decides to fulfill the budget deficit using borrowings without introducing additional taxes, it creates a liability that is called public debt (Moki, 2012). That public debt can be classified as productive debt and unproductive debt. When that debt uses for development purposes as examples for infrastructure, acquiring factories, refineries, etc, it is called productive debt. That debt supports to generate capital and economic development. However, unproductive debt is taken over to finance wars and expenses on current expenditure. This would not imply a production and losses with the consumption (Chowdhury, 2001). The debt structure of any country affects individual citizens, institutions of government, private companies like banks as well as the whole economy at large. The debt structure is the magnitude of the domestic debt and external debt (Obademi, 2012). Further, CBSL (2004) expresses that a government has many domestic alternatives to borrow to finance the budget deficit. Such as borrowing from the central bank directly by printing money, borrowing from domestic banks and the domestic non-bank sector as well as government can finance budget deficit borrowing from external sources. The government usually follows mix strategy and utilizes a number of options that are more advantageous for the present situation of the country at the same time (Rais and Anwar, 2012).

Sri Lanka is the one of less developed countries that continually has a budget deficit since 1956. Central Bank of Sri Lanka (2019) stated that the overall budget deficit as a percentage of GDP increased to 6.8 percent (Rs.1016.5 billion) in 2019 from 5.3 percent (Rs.760.8 billion) in 2018. To fulfill that budget deficit, the government borrowed from both domestic and external sources. In such a situation, public debt servicing is also heavily highlighted in Sri Lanka. The debt servicing payments are the combination of amortization payments and interest payments. Public debt plays a major role in economic performance in Sri Lanka. Therefore it is essential to identify the effects of public debt on economic performance using economic growth as the better variable that can measure the economic performance in Sri Lanka. Economic growth expresses that changing material production during a relatively short period (usually one year). In such a situation, the Central Bank of Sri Lanka (2019) further expressed Sri Lankan economic growth grew slowly at 2.3 percent in 2019 compared with 3.3 percent in 2018 generating from the domestic and external challenges. Therefore this situation creates a problem for researchers to have new analysis regarding the relationship between public debt and economic growth in Sri Lanka.

*Corresponding author: Tel.: +94 (71) 401 8986; Email: hansi.wgchamodi@gmail.com https://orcid.org/0000-0001-7539-1470 


\section{PROBLEM STATEMENT}

Economists do not consider public debt as a major problem. But they identified problems as mismanagement and unsustainability of the public debt. The stagy increase of public debt in less developed countries has increased concerns as to whether the borrowings would help to improve economic growth or whether it would become a burden of responsibility that future generations would have to pay (Lee and Ng, 2015). The analysis of the public debt in less developed countries has traditionally focused on external debt. Past research has paid attention to external debt because of two reasons. The first one is external debt can expand the access of a country to resources and domestic debt only transfers resources within the country from one place to another. Hence, only external debt generates a transfer problem (Rueff, 1929). The second one is central banks in less developed counties cannot print the hard currency necessary to repay external debt. Because external borrowing is usually related to vulnerabilities that may lead to debt crises (Panizza, 2009).

Over the last few decades, the factors affecting economic growth in less developed countries have been a topic of debate. Most researchers concluded that economic growth in a country was associated with levels of investment, government expenditure, life expectancy, levels of schooling, public debt, inflation rate, foreign direct investment, the productivity of factors of production, level of natural resources, the openness of trade and level of democracy, etc (Barro, 1996; Sachs and Warner, 1995; Kumar and Woo, 2010; Cervellati and Sunde, 2011 and Caves, 1971). Among them, this research attempts to identify the effects of public debt on economic growth in Sri Lanka. In early mixed findings, there is no much clearance of the impact of debt on economic growth. Furthermore, there is even less evidence on discussing which debt affects growth. Geiger (1990) and Chowdhury (1994) studied different countries' preface of foreign debt on economic growth. They concluded that the effectiveness of debt on economic growth differs from country-to-country because their findings showed various results. Therefore international findings regarding public debt on economic growth cannot apply to the Sri Lankan context.

Sri Lanka is recognized as a middle-income country, and therefore the country is forced to finance public investment more from borrowing rather than from grants which will result in high public debt (Kumara and Cooray, 2013). The questions remain whether the government can achieve high economic growth by public investment through heavy debt, what is the relationship of public domestic debt, public external debt, and public debt servicing on economic growth in Sri Lanka. Those are some issues that this study attempt to discuss. There are many studies considered about debtgrowth nexus and they mainly focus on the countries that have vast access to the international capital market. Therefore presumptions based on those studies limited relevance to the Sri Lankan context. There are some studies regarding Sri Lankan public debt (Jha and Schatan, 2001; Kappagoda, 2004; Fonseka and Ranasinghe, 2007; Ekanayake, 2011). But few studies have addressed the relationship between public debt and economic growth. Kumara and Cooray (2013) studied the effects of public debt on economic growth in Sri Lanka and the above issues. But they did not pay attention to studying the effects of domestic and external debt separately on economic growth in Sri Lanka. Therefore, this study aims to fill this gap by including the following. (a) To find the relationship between public debt and economic growth in Sri Lanka (b) To find the relationship between domestic and external debt separately on economic growth in Sri Lanka. (c) To find out the relationship between public debt servicing and GDP growth in Sri Lanka. And most studies engaged with the effects of external debt on economic growth instead of studying domestic debt in other countries (Malik, Hayat, \& Hayat, 2010). Even in Sri Lanka, most research papers studied about effects of external debt on economic growth (Wijeweera et al., 2005).

\section{RESEARCH OBJECTIVES}

This study investigates the effects of public debt on economic growth in Sri Lanka as the main objective. Further, it studies the relationship between public domestic debt and economic growth in Sri Lanka, the relationship between public external debt and economic growth in Sri Lanka, and the relationship between public debt service payment and economic growth in Sri Lanka as specific objectives.

\section{LITERATURE REVIEW}

There are some theories related to the relationship between public debt and economic growth. Such as the neo-classical theory, Buchanan theories, the Debt overhang theory, and Keynesian theory of public debt. Among them, this paper discusses the Keynesian theory of public debt as one of the major theories related to public debt and economic growth. The Keynesian theory of public debt shows an expansion of government debt is a burden and an increase in government spending is an expansionary fiscal shock to the economy. If the revenue of the country is lower than the spending which in results an enhance in demand for goods and services, an increase in government spending results in the public debt contraction. The demand for goods and services is due to the situation that there will be more money chasing few goods and services in the economy and the view of sticky prices in the short run, increased demand will raise output and employment. When the marginal propensity to save is lower than the marginal propensity to consume, the increase in private savings reduces short of the government de-saving. As a result of this, the real interest rate would increase in the economy to encourage capital inflow from abroad. An enhance of capital inflows implies the attraction of foreign direct investment and it affects to rise in investment level. An increase in investment level affects the rise of savings and increase aggregate demand and GDP (Ntshakala, 2015).

Panizza and Presbitero (2013) investigated the recent literature on the relationship between public debt and economic growth in advanced economies. They concluded that theoretical models create ambiguous results. Further, they stated that there is a very limited paper that can build a strong case for a causal relationship between public debt and economic growth. However, empirical findings regarding the impact of domestic debt and external debt on economic growth had found by Atique and Malik (2012) separately in Pakistan from 1980 to 2010 using GDP growth rate, debt servicing, inflation, investment, and labour force. Their findings suggested that the negative impact of both domestic and external debt on economic growth and those relationships were significant as well while Stylianou (2014) shows the no causality that going from debt to economic growth in Greece after studying the variables of public debt and economic growth from 1980 to 2010 . However, the majority of empirical findings regarding public debt and economic growth show negative and no causality mixed results. 
Further, Geiger (1990) and Chowdhury (1994) studied the role of foreign debt on economic growth in different countries. They concluded that the effectiveness of debt on economic growth differs from country-to-country because their findings showed various results. Therefore, findings of the effects of public debt on economic growth in Sri Lanka need to be unique. Sri Lanka paid high attention to finance public investment through borrowing rather than through grants which will result in high public debt (Kumara and Cooray, 2013). In such a situation, some issues occur such as whether the government can achieve high economic growth through public investment through heavy debt. Does debt reduction increase growth? There are some studies available regarding the Sri Lankan public debt (Jha, 2001; Kappagoda, 2004; Fonseka and Ranasinghe, 2007; Ekanayake, 2011). But few studies have addressed the relationship between public debt and economic growth and the issues mentioned above. Kumara and Cooray (2013) studied about above issues but they did not pay attention to studying domestic and external debt separately. Therefore, this study aims to fill this gap by using the latest data to analyze the impact of domestic debt, external debt, and debt servicing on the Sri Lankan economy separately and to address the above issues that have mentioned.

Many studies support a non-linear effect of external debt on growth including Smyth and Hsing (1995). On the other hand, the linear negative relationship between external debt and per-capita growth was found by Schclarek (2004) using 59 less developed countries from 1970 to 2002. Shah and Pervin (2012) tried to review and analyze the behavior of public debt burden on the economic growth of Bangladesh using a vector autoregression model for a study period of 1974-2010 and finally, they found that external debt service and economic growth are negatively affected while external public debt and economic growth are positively related in long run. In the short run, there is no effect of external public debt on economic growth and only external debt service has a negative effect on economic growth. Since this is a secondary data analysis, the majority of research papers follow the same tools for analyzing data (Unit root test, Cointegration test, Error correction model, etc). But the majority of Sri Lankan studies did not pay attention to multicollinearity, heteroscedasticity, and normality test with the other tests (Kumara and Cooray (2013). But this research attempts to have all related tests and to have more accruable findings with proofs.

\section{CONCEPTUAL FRAMEWORK}

Most researchers concluded that economic growth in a country is associated with levels of investment, government expenditure, life expectancy, levels of schooling, public debt, inflation rate, foreign direct investment, the productivity of factors of production, level of natural resources, the openness of trade and level of democracy, etc (Barro, 1996; Sachs and Warner, 1995; Kumar and Woo, 2010; Cervellati and Sunde, 2009 and Caves, 1971). Among them, this research attempts to identify the effects of public debt on economic growth in Sri Lanka. Therefore, public debt considers as the major independent variable that influences economic growth in this study.

This study focuses on the Keynesian theory of public debt that considers large public debt as a national asset instead of taking it as a liability. Further, this theory states that a steady deficit spending normally joins with a country's economic progress and assumes public debt is fully employed.
According to Keynes's view, if there were unemployed resources, those can be used by budget deficit while neoclassical states that the economy is always at the full employment level. Keynes further clarified that national income can be expanded multiple times by increasing public debt and he states that public debt is necessary to fulfill all purposes of government and it will have resulted in increasing effective demand, employment, and output. Keynes did not classify public debt in a productive and unproductive manner as classical economists. But he paid attention to borrowing for consumption same as borrowings for investment because consumption expenditure also affects to expand investment through increasing demand for goods and services. Therefore, this study follows Keynesian growth theory with some modifications and the specialized model can be shown as follows.

$\mathrm{Y}=\mathrm{C}+\mathrm{I}+\mathrm{G}+\mathrm{NX} \quad$ (1)

Where, $Y=$ Income (Real Gross Domestic Product considers as proxy), $\mathrm{C}=$ Private Consumption, $\mathrm{I}=$ Private Investment, $\mathrm{G}=$ Government Expenditure and NX = Net Export

Since this study investigates the effects of public debt on economic growth in Sri Lanka, the Real Gross Domestic Product growth rate (RGDPgr) has taken as the proxy for the dependent variable, and public debt is separated as domestic debt and external debt because public debt consists two parts as public and publically guaranteed external debt and domestic debt (Akram, 2015). And Internal debt and external debt are the same in the aspect that debt burden should be borne in the future when forcible taxation is levied to service and release the debt (Cohen, 1993). But they are two concepts of public debt and those are affected by economic growth in different aspects. As an example, Atique and Malik (2012) argued that there was a significant negative effect of domestic and as well as external debt on economic growth. They further concluded that the negative effect of external debt on GDP is stronger than the negative effect of domestic debt. According to Akram (2011), the indicators of public debt are categorized as (1) Stock Variables: this implies the value of debt burden to different key indicators. Ex. External debt GDP ratio, domestic debt GDP ratio, debt export ratio. The most used indicator to judge the stock of public debt is its ratio to GDP. (2) Flow Variables: this focuses on debt service payment. Therefore, this study adds domestic and external debt as independent variables separately, further including public debt servicing.

Figure 1: Conceptual Framework

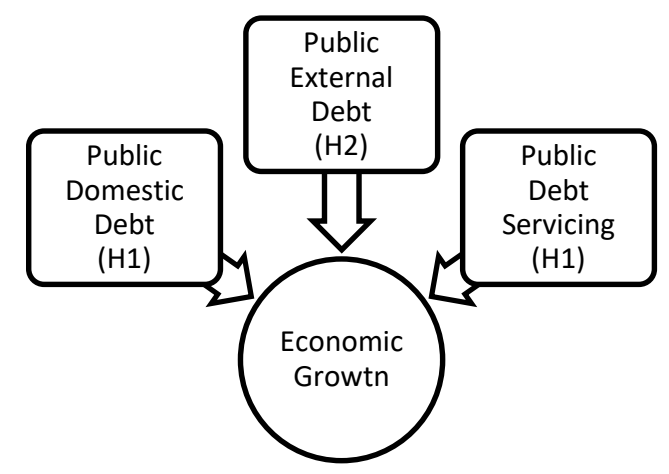

\section{DEVELOPING HYPOTHESIS}

The empirical studies regarding the relationship between domestic debt and economic growth are showed mixed findings as positive and negative relationships. However, the majority of studies concluded that there is a negative relationship between domestic debt and economic growth. As 
an example, Jebran, Hayat, and lqbal (2016) showed a negative relationship going from domestic debt to economic growth after studying the behavior of external debt, domestic debt, debt service, and inflation on GDP in Pakistan from 1972 to 2012. Further, Anyanwu and Erhijakpor (2004) studied the effects between current domestic debt outstanding as a ratio of GDP and growth in Nigeria for the period of 1970 to 2003. Their results show that current domestic debt outstanding as a ratio of GDP has a significantly negative effect on economic growth. And also Adofu and Abula (2010) investigated the empirical relationship between domestic debt and economic growth again for Nigeria using time series data from 1986 to 2005. They concluded that domestic debt and economic growth have a negative relationship and it is better to discourage domestic debt and encourage public revenue. Therefore this study is also proposed to have a negative relationship between domestic debt and economic growth.

H1: There is a negative relationship between domestic debt and economic growth

The empirical studies regarding the relationship between external debt and economic growth are showed mixed findings as positive and negative relationships. However, the majority of studies concluded that there is a negative relationship between external debt and economic growth. As an example, Yeasmin, Chowdhury, and Hossian (2015) investigated the behavior of external debt on economic growth in Bangladesh from 1972 to 2012 using variables of GDP, external debt, investment, and employment and the results showed that significant adverse effect of external debt to economic growth. Further, Schclarek (2005) studied the behavior of per capita GDP growth rate, total debt to GDP ratio, public debt to export ratio, public external debt to export ratio, private external debt to GDP ratio, etc. using panel data of 24 industrial countries and 59 developing countries from 1970 to 2002 and concluded that public external debt and per capita GDP have a negative relationship in developing countries. Further, he stated that public external debt and per capita GDP are not interrelated in industrial countries. Besides, Safadari and Mehrizi investigated the relationship between external debt and economic growth in Iran for the period of 1974 to 2007 using five variables (gross domestic product, private investment, public investment, external debt, and imports. The results show that external debt had a negative relationship with economic growth. Therefore this study is also proposed to have a negative relationship going from external debt to economic growth.

H2: There is a negative relationship between external debt and economic growth

The empirical studies regarding the relationship between debt servicing and economic growth showed mixed findings as negative and no relationships. However, the majority of studies concluded that there is a negative relationship between debt servicing and economic growth. As an example, Afonso and Alves (2014) studied the role of government debt in economic growth in 14 European countries from 1970 to 2012 using domestic debt and real per capita GDP. They concluded that debt servicing has a 10 times worst effect on growth. Further, Jebran, Hayat, and Iqbal (2016) studied the effects of public debt on economic growth in $\mathrm{Pa}$ kistan using GDP, domestic debt, external debt, and debt servicing from 1972 to 2012. They found out that debt servicing is inversely related to GDP in the short-run. And also Sheikh, Faridiand Tariq (2010) investigated the relationship between domestic debt and economic growth in Pakistan for the period of 1972 to 2009 . The study concluded that domestic debt and economic growth have a positive relationship and it observes that there is an adverse effect of public debt servicing on economic growth. Therefore this study is also proposed to have a negative relationship going from debt servicing to economic growth.

H3: There is a negative relationship between debt servicing and economic growth

\section{RESEARCH METHODOLOGY}

Data collection: This study used annual time series data from 1980 to 2019 which translates to 40 observations. Data for public domestic debt, public external debt, public debt servicing were obtained from the Central Bank of Sri Lanka (2019)

Analytical model: After the adoption of Keynesian growth model, mathematical equation number 2 has been derived after transforming equation 1 as follows.

$R G D P=f(D o D, E x D, D S e r)$

The following econometric equation 3 has been derived using the above equation 2

$R_{G D P_{t}}=\beta 0+\beta 1 D_{0} D_{t}+\beta 2 E D_{t}+\beta 3 D_{\text {Ser }}$

The majority of research papers followed non-linear regression model to investigate the relationship between public debt and economic growth (Checherita and Rother, 2010; Yeasmin, Chowdhury and Hossain, 2015; Eberhardt and Presbitero, 2015 and Schclarek, 2005) while Kumara and Cooray (2013) estimate the linear regression model to have the relationship between public debt and economic growth using OLS and then model is estimated with non-overlapping averages for two years. But logarithm of the public debt to GDP ratio is no significant in both cases. This implies that there is no evidence to have a linear relationship going from public debt to GDP per capita in Sri Lanka. Because of that they also followed nonlinear regression for their study. Therefore, this study also proposes a non-linear regression model to estimate the following relationship.

$\mathrm{LNGDP}_{\text {grt }}=\beta 0+\beta 1 \mathrm{LNDoD}_{\mathrm{t}}+\beta 2 \mathrm{LNExD}_{\mathrm{t}}+\beta 3 \mathrm{LNDSer}_{t}+\varepsilon_{\mathrm{t}}$ (4) Where, $\mathrm{LNGDP}_{\mathrm{grt}}=$ Natural log of Real Gross Domestic Product Growth Rate at time $t, L^{2 N D o D_{t}}=$ Natural log of Public Domestic Debt as a \% of GDP at time $t$, LNExD $_{t}=$ Natural log of Public External Debt as a \% of GDP at time t, LNDSer $_{t}=$ Natural Log of Public Debt Servicing Ratio at time $t, t=$ time, $\varepsilon_{\mathrm{t}}=$ the error term assumed to be normally and independently distributed with mean zero and constant variance, $\beta 0=$ captures all other independent variables which affect growth, but are not captured in the model and $\beta 1, \beta 2$ and $\beta 3$ are the coefficients of economic growth respect to LNDoD, LNEXD, and LNDSer respectively. Here public debt servicing is the combination of principal repayments and interest payments.

Preliminary data analysis: Before running the regression model for the specified data set using Eviews 7.0 version, descriptive statistics used to show the behavior of the selected independent and dependent variables to have the general idea of those variables and the Jacque Bera coefficient has selected to investigate the normality of the data set. This model assumes that Ordinary Least Square (OLS) and time-series models are based on the assumption of normality, linearity, homoscedasticity, no multicollinearity, and stationarity.

The stationarity test and Augmented Dickey-Fuller (ADF) test that have specified the order of integration will be used 
here because this study follows the time series data set. Further, this expects to show the long-run relationship among selected variables using the two-step Engle-Granger test for cointegration and this study shows the short-run relationship using cointegration and an error correlation model.

\section{RESULTS AND DISCUSSION}

Descriptive statistics and normality test: When analyzing time series data, the initial step is to investigate whether the Table 01: Descriptive statistics

\begin{tabular}{|c|c|c|c|c|}
\hline & LNGDPGR & LNDOD & LNEXD & LNDSER \\
\hline Mean & 1.5685 & 3.8014 & 3.7290 & 2.8712 \\
\hline Median & 1.6094 & 3.7762 & 3.7376 & 2.8506 \\
\hline Maximum & 2.2083 & 4.0943 & 4.1271 & 3.3911 \\
\hline Minimum & 0.4055 & 3.5145 & 3.4078 & 2.0669 \\
\hline Std.Dev. & 0.3730 & 0.1245 & 0.2072 & 0.3186 \\
\hline Skewness & -0.9542 & 0.4424 & 0.1653 & -0.0779 \\
\hline Kurtosis & 4.2130 & 3.0465 & 1.8358 & 2.3827 \\
\hline Jarque-Bera & 8.3094 & 1.3082 & 2.4411 & 0.6756 \\
\hline Probability & 0.0157 & 0.5199 & 0.2951 & 0.7133 \\
\hline Sum & 61.1704 & 528.1889 & 525.3029 & 506.2586 \\
\hline Sum Sq. Dev. & 5.2874 & 0.6046 & 1.6748 & 3.9572 \\
\hline Observations & 39 & 40 & 40 & 40 \\
\hline
\end{tabular}

Source: Made by Author, 2020.

Table 1 presents the results of descriptive statistics of all the variables from 1980 to 2019. It shows that the distribution JB probabilities for LNGDPGR are 0.0157, LNDOD is 0.52, LNEXD is 0.30 and LNDSER is 0.71 (for a normal distribution, the probability should be greater than 0.05 ). Therefore, we conclude that all the independent variables (i.e LNDOD, LNEXD, and LNDSER) in our study are normally distributed and LNGDPGR is not normally distributed. Further, the reason for having 39 observations for LNGDPGR is the difficulty of converting a negative growth rate $(-1.5)$ in 2001 into natural log form.

Unit Root test of the variables: When a study uses non-stationary series as stationary, it will bias the Ordinary Least

Table 02: Unit Root Test at Level variables under study are normally distributed. Descriptive statistics were checked putting keen interest on the JargueBera probability to test for normality of the variables.

$\mathbf{H}_{0}: \mathrm{JB}=0$ (normally distributed) and $\mathbf{H}_{1}: J B \neq 0$ (not normally distributed)

When the null hypothesis rejects, it implies that the variable is not normally distributed and a logarithmic transformation is necessary.
Squares (OLS) and finally the results would be misleading. For that reason, when estimating a model that includes time series variables, there is a want to make sure that all-time series variables in the model are stationary or are cointegrated. It means that they are integrated of the same order and the error term or residual is stationary in which case the model expresses a long-run equilibrium relationship among the cointegrated variables.

This study uses ADF (Augmented Dickey-Fuller) test to check the unit root of the time series data by EViews 7. The hypothesis can develop as follows.

$\mathbf{H}_{\mathbf{0}}$ : Time series is non-stationary and $\mathbf{H}_{\mathbf{1}}$ : Time series is stationary

ADF Unit root for sample period 1980-2019

At Level with intercept

\begin{tabular}{lrrrrrl}
\hline Variable & ADF: tstatistic & $\mathbf{1 \%}$ & $\mathbf{5 \%}$ & $\mathbf{1 0 \%}$ & Probability & Remarks \\
LNGDPGR & -3.5662 & -3.6210 & -2.9434 & -2.6103 & 0.0115 & Stationary (0) \\
LNDOD & -1.9958 & -3.6105 & -2.9390 & -2.6079 & 0.2874 & Non-stationary (0) \\
LNEXD & -1.5055 & -3.6105 & -2.9390 & -2.6079 & 0.5203 & Non-stationary (0) \\
LNDSER & -1.9077 & -3.6105 & -2.9390 & -2.6079 & 0.3255 & Non-stationary (0) \\
\hline
\end{tabular}

Source: Made by Author, 2020.

Table 03: Unit Root Test at 1st deference

ADF Unit root for sample period 1980-2019

At 1st deference with intercept

\begin{tabular}{lrrrrrl}
\hline Variable & ADF: tstatistic & $\mathbf{1 \%}$ & $\mathbf{5 \%}$ & $\mathbf{1 0 \%}$ & Probability & Remarks \\
LNDOD & -6.0197 & -3.6159 & -2.9411 & -2.6091 & 0.2874 & Stationary (1) \\
LNEXD & -6.0010 & -3.6159 & -2.9411 & -2.6091 & 0.5203 & Stationary (1) \\
LNDSER & -6.7320 & -3.6159 & -2.9411 & -2.6091 & 0.3255 & Stationary (1) \\
\hline
\end{tabular}

Source: Made by Author, 2020. 
Above table 2 and 3 above show that the dependent variable (LNGDPGR) is stationary at I(0) while all independent variables (LNDOD, LNEXD, and LNDSER) non-stationary at I(0) but stationary at I(1). When there are non-stationary variables, their regression leads to produce a spurious regression. But spurious regression may not occur if independent variables are co-integrated with the dependent variable. So, it needs to have co-integration among the variable.

Co-integration test: Co-integration is the statistical tool that uses to find the long-run relationship between independent and dependent variables (Granger and Newbold, 1974). If the residuals obtained from the co-integrated equation are stationary I(0), the linear relationship of non-stationary variables becomes co-integrated. This study follows EngleGranger two steps co-integration test and it is a residual base test. The first step is to have the regression model and secondly, residual series needs to generate using Eviews software with relevance to the ADF test. The error term is expected to be stationary at the level and it will be co-integrated.

$\mathbf{H}_{0}$ : Residual series is non-stationary and $\mathbf{H}_{\mathbf{1}}$ : Residual series is stationary

Table 04: Co-integration

Dependent Variable: LNGDPGR

Method: Least Squares

Date: 08/22/20 Time: 02.18

Sample: 19802019

Included Observations: 39

\begin{tabular}{|c|c|c|c|c|}
\hline Variable & Coefficient & Std. Error & t-statistic & Prob. \\
\hline LNDOD & -0.8345 & 0.3542 & -2.3564 & 0.0242 \\
\hline LNEXD & -0.7156 & 0.1818 & -3.9364 & 0.0004 \\
\hline LNDSER & -0.8838 & 0.1310 & -6.7491 & 0.0000 \\
\hline C & 9.9454 & 1.6191 & 6.1433 & 0.0000 \\
\hline R-squared & 0.6402 & Mean dependent var. & & 1.568 \\
\hline Adjusted R-squared & 0.6094 & S.D dependent var. & & 0.3730 \\
\hline S.E of regression & 0.2331 & Akaike info criterion & & 0.0225 \\
\hline Sum squared resid & 1.9023 & Schwarz criterion & & 0.1932 \\
\hline Log likelihood & 3.5607 & Hannan-Quinn criterion & & 0.0837 \\
\hline F-statistic & 20.7601 & Durbin-Watson stat & & 2.4213 \\
\hline Prob(F-statistic) & 0.0000 & & & \\
\hline
\end{tabular}

Source: Made by Author, 2020.

Table 05: Co-integration

Augmented Dickey-Fuller Test Equation

Dependent Variable: D(RESID01)

Method: Least Squares

Date: 08/22/20 Time: 04.23

Sample: 19802019

Included Observations: 37 after adjustment

\begin{tabular}{|c|c|c|c|c|}
\hline Variable & Coefficient & Std. Error & t-statistic & Prob. \\
\hline RESID01(-1) & -1.2598 & 0.1622 & -7.7676 & 0.0000 \\
\hline R-squared & 0.6259 & Mean dependent var. & & 0.0107 \\
\hline Adjusted R-squared & 0.6259 & S.D dependent var. & & 0.3529 \\
\hline S.E of regression & 0.2158 & Akaike info criterion & & -0.2019 \\
\hline Sum squared resid & 1.6771 & Schwarz criterion & & -0.1583 \\
\hline Log likelihood & 4.7352 & Hannan-Quinn criterion & & -0.1866 \\
\hline Durbin-Watson stat & 2.0389 & & & \\
\hline
\end{tabular}

Source: Made by Author, 2020.

The Engle-Granger 5 percent test critical value is -1.9501 and the ADF test statistic is -7.7676 . Since the ADF test statistic is more negative than the test critical value, residuals of the regression have not the unit root. That is they are stationary at level. It concludes that independent variables are co-integrated with the dependent variable. Therefore, regression may not spurious.

The regression coefficient regarding the public domestic debt is -0.8345 means that when public domestic debt increases by 1 percent, the GDP growth rate decreases by 0.8345 percent. When external debt increases by 1 percent, economic growth decreases by 0.7156 percent while GDP growth reduces by 0.8838 percent concerning a 1 percent increment of public debt servicing. Economic growth expands by 9.9464 percent due to the percentage changing of other variables instead of selected independent variables. Above all results are statistically significant.
Error correlation model (ECM): The error correlation model uses to capture the short-run relationship between selected variables (Granger and Newbold, 1974). Variables are used in the first difference to construct this model. The ECM consists of the lagged error term derived from the cointegrating equation. This is termed as the rate of adjustment per quarter of negative coefficient and the error correction. The required lag length was determined by using Schwarz Information Criterion (SIC).

Table 5 expresses the error correction model and it indicates the negative behavior of coefficient of error term with GDP growth as theoretically expected. Further, it is statistically significant at a 5 percent confidence level. Then any deviation from the equilibrium that occurs by a variable will be corrected in near future because of that negative sign. The error coefficient shows that $123 \%$ of any disequilibrium that is included in the cointegrating model will be corrected next 
Table 06: Error Correlation Model (ECM)

Dependent Variable: D(LNGDPGR)

Method: Least Squares

Date: 02/1/6 Time: 00.06

Sample: 19802019

Included Observations: 37 after adjustment

\begin{tabular}{|c|c|c|c|c|}
\hline Variable & Coefficient & Std. Error & t-statistic & Prob. \\
\hline $\mathrm{C}$ & 0.0051 & 0.0366 & 0.1382 & 0.8910 \\
\hline $\mathrm{D}($ LNDOD) & -1.1080 & 0.5307 & -2.0877 & 0.0449 \\
\hline$D($ LNEXD) & -1.1162 & 0.4852 & -2.3005 & 0.0281 \\
\hline$D($ LNDSER) & -0.5839 & 0.1990 & -2.9341 & 0.0061 \\
\hline $\operatorname{RESID1}(-1)$ & -1.2387 & 0.1677 & -7.3860 & 0.0000 \\
\hline R-squared & 0.7424 & Mean dependent var. & & -0.0140 \\
\hline Adjusted R-squared & 0.7102 & S.D dependent var. & & 0.4086 \\
\hline S.E of regression & 0.2180 & Akaike info criterion & & -0.0655 \\
\hline Sum squared resid & 1.5486 & Schwarz criterion & & 0.1522 \\
\hline Log likelihood & 6.2108 & Hannan-Quinn criterion & & 0.0113 \\
\hline F-statistic & 23.0515 & Durbin-Watson stat & & 1.8995 \\
\hline Prob(F-statistic) & 0.0000 & & & \\
\hline
\end{tabular}

Source: Made by Author, 2020.

year. This states that the GDP equilibrium is maintaining by explanatory variables throughout time.

The results reveal that when domestic debt increases by 1 percent, the GDP growth rate decreases by 1 percent. The external debt is also negatively related and when it increases by 1 percent, the GDP growth rate reduces by 1.1 percent. When debt servicing increases by 1 percent, the GDP growth rate decreases by 0.5 percent. All independent variables are negatively related to GDP growth rate and all are significant at a 5 percent confidence level. When domestic debt, external debt, and debt servicing become zero, the GDP growth rate is 0.005 (effect on other variables without explanatory variables). The probability of the $\mathrm{F}$ statistic in the model is equal to zero. It means that regression is overall significant. Finally, the adjusted $R$ squared shows as 0.71 . This stated that 71 percent of the variation of GDP growth rate expresses by the regression.

Multicollinearity test: Simply, multicollinearity implies that the linear relationship between all independent variables of a regression model. There are several methods of identifying multicollinearity in a regression model. This study follows the Variance Inflation Factor (VIF) as one of the methods among them to identify the multicollinearity. VIF expresses that if the VIF value of a regression model is less than 10, there is no multicollinearity. But if that value exceeds 10 , that regression model consists of severe multicollinearity. Then the results will be misleading. Here this study has two regression models as the short-run model and the long-run model. Therefore, I expect to identify multicollinearity for both short-run and long-run period separately.

Table 07: Multicollinearity for Long run regression

\begin{tabular}{lccr}
\hline \multicolumn{4}{l}{ Variance Inflation Factor } \\
$\begin{array}{l}\text { Date: 02/10/06 } \\
\text { Time: 05.42 }\end{array}$ & & \\
Sample: 1980 & 2019 & & \\
Included Observations: 39 & & \\
\hline \multirow{2}{*}{ Variable } & $\begin{array}{c}\text { Coefficient } \\
\text { Variance }\end{array}$ & $\begin{array}{c}\text { Uncentered } \\
\text { VIF }\end{array}$ & $\begin{array}{c}\text { Centered } \\
\text { VIF }\end{array}$ \\
\hline C & 2.6214 & 1880.950 & NA \\
LNDOD & 0.1254 & 1297.196 & 1.2364 \\
LNEXD & 0.0330 & 330.3427 & 1.0138 \\
LNDSER & 0.0171 & 103.1960 & 1.2211 \\
\hline
\end{tabular}

Source: Made by Author, 2020.
Table 08: Multicollinearity Test for short run

\begin{tabular}{lccr}
\hline \multicolumn{4}{l}{$\begin{array}{l}\text { Variance Inflation Factor } \\
\text { Date: 02/10/06 }\end{array}$ Time: 05.52 } \\
Sample: 1980 2019 \\
Included Observations: 37 \\
\hline \multirow{2}{*}{ Variable } & $\begin{array}{c}\text { Coefficient } \\
\text { Variance }\end{array}$ & $\begin{array}{c}\text { Uncentered } \\
\text { VIF }\end{array}$ & $\begin{array}{c}\text { Centered } \\
\text { VIF }\end{array}$ \\
\hline C & 0.0013 & 1.0258 & NA \\
D(LNDOD) & 0.2816 & 1.3237 & 1.3222 \\
D(LNEXD) & 0.2354 & 1.3695 & 1.3651 \\
D(LNDSER) & 0.0396 & 1.3179 & 1.2966 \\
\hline
\end{tabular}

Source: Made by Author, 2020.

Since all VIF values in both short-run and long-run regression models are below 10 , it can conclude that there is no multicollinearity and results may not spurious.

Heteroscedasticity test: Heteroscedasticity shows that the variance of disturbance term or error term is not equal. But when we regress a model, we assume that there is homoscedasticity or no heteroscedasticity in the regression model. This study shows that the situations of heteroscedasticity for both short-run and long-run regression models. The hypothesis can develop as follows related to heteroscedasticity.

HO: There is no heteroscedasticity in the model.

$\mathrm{H} 1$ : There is heteroscedasticity in the model.

Table 09: Heteroscedasticity for Long run regression

\begin{tabular}{|c|c|c|c|}
\hline \multicolumn{4}{|c|}{ Heterocadasticity Test: Breush-Pagan-Godfrey } \\
\hline F-statistic & 0.9992 & Prob. F(3.35) & 0.4047 \\
\hline $\begin{array}{l}\text { Obs*R- } \\
\text { Squared }\end{array}$ & 3.0767 & Prob. Chi-Square(3) & 0.3800 \\
\hline $\begin{array}{l}\text { Scaled } \\
\text { explained SS }\end{array}$ & 2.7980 & Prob. Chi-Square(3) & 0.4238 \\
\hline
\end{tabular}

Source: Made by Author, 2020.

Table 10: Heteroscedasticity for short-run regression

\begin{tabular}{|c|c|c|c|}
\hline \multicolumn{4}{|c|}{ Heterocadasticity Test: Breush-Pagan-Godfrey } \\
\hline F-statistic & 0.7481 & Prob. F(4.32) & 0.5666 \\
\hline $\begin{array}{l}\text { Obs*R- } \\
\text { Squared }\end{array}$ & 3.1641 & Prob. Chi-Square(4) & 0.5308 \\
\hline $\begin{array}{l}\text { Scaled ex- } \\
\text { plained SS }\end{array}$ & 2.0987 & Prob. Chi-Square(4) & 0.7176 \\
\hline
\end{tabular}

Source: Made by Author, 2020. 
The probability of Chi-Square in both short-run and long-run model are not significant at 0.05 confident level. Therefore we can accept the null hypothesis means that both models consist of homoscedasticity or no heteroscedasticity. That means the variance of the error term in both models is equally distributed.

Since the probability value for the domestic debt variable is less than 0.05 in both the short-run (0.0449) and long-run (0.0242), this study has a piece of evidence to accept alternative hypothesis $(\mathrm{H} 1)$ that implies an adverse relationship between public domestic debt and economic growth. In addition to that, the probability value for the external debt variable was 0.0281 in the short run and 0.0004 in long run. Since those values are less than 0.05 confidence level, this study has evidence to accept alternative hypothesis $(\mathrm{H} 2)$ that shows a negative relationship between public external debt and economic growth. Further, this study has evidence to reject the null hypothesis and accept the alternative hypothesis $(\mathrm{H} 3)$ due to the probability value for the debt servicing variable is less than 0.05 in both the short-run (0.0062) and long-run (0.0000).

\section{CONCLUSION}

The main objective of this study to investigate the relationship between public debt and economic growth in Sri Lanka for the period of 1980 to 2019. This paper uses econometric tools that normally uses in time series analysis using GDP growth rate as the dependent variable and public domestic debt, public external debt, and public debt servicing as explanatory variables. As a result, all independent variables (Domestic debt, External Debt, and Debt servicing) are adversely related to economic growth. Therefore this study reached the objectives that express the negative relationship between all independent variables and economic growth. That means the public debt level in Sri Lanka exceeds the optimal level of public debt. Therefore, this study concludes that overall public debt has a negative effect on economic growth in Sri Lanka. When the results compare with similar studies, the majority had concluded that public debt has a negative effect on economic growth such as Panizza and Presbitero (2014), Lee and Ng (2015), Ahlborn and Schweickert (2018), etc. Debt is very important to the development and growth of Sri Lanka. In such a situation, there is not support of public debt on economic growth in Sri Lanka according to this analysis. And also that public debt cost is heavily for low-income people as tax. This paper implies that if Sri Lanka arranges more public debt, it will be led to huge failure in the country.

This study ensures Keynsian theoretical model that expresses the negative relationship between public debt and economic growth after the threshold level.

According to the findings of the present study, it can suggest a few policy implications such as effective usage of public debt on development activities, divisibility of export would be supported to reduce the budget deficit, avoiding corruptions, handling savings in an effective way for development activities instead of depending high debt, avoiding high imports of non-essential products, reducing wasting or unnecessary expenses of government, encouraging private sector for huge investment inside the country and ensuring effectiveness among government institutions to have a high income.

\section{REFERENCES}

Adofu, I., \& Abula, M. (2010). Domestic debt and the Nigerian economy. Current Research Journal of Economic Theory, 2(1), 22-26.

Afonso, A., \& Alves, J. (2014). The role of government debt in economic growth. ISEG-UTL Economics Department Working Paper, (16).

Ahlborn, M., \& Schweickert, R. (2018). Public debt and economic growth-Economic systems matter. International Economics and Economic Policy, 15(2), 373-403.

Akram, N. (2011). Impact of Public Debt on the economic growth of Pakistan. The Pakistan Development Review, 599-615.

Akram, N. (2015). Is public debt hindering the economic growth of the Philippines?. International Journal of Social Economics.

Anyanwu, J. C., \& Erhijakpor, A. E. (2004). Domestic debt and economic growth: The Nigerian case. West African Financial and Economic Review, 1(2), 98-128.

Atique, R., \& Malik, K. (2012). Impact of domestic and external debt on the economic growth of Pakistan. World Applied Sciences Journal, 20(1), 120-129.

Barro, R. J. (1979). On the determination of the public debt. Journal of Political Economy, 87(5, Part 1), 940-971.

Barro, R. J. (1996). Determinants of economic growth: A cross-country empirical study (No. w5698). National Bureau of Economic Research.

Caves, R. E. (1971). Export-led growth and the new economic history. Trade, the balance of payments and growth, 403-42.

Central Bank of Sri Lanka (CBSL), Annual Report, 2004

Central Bank of Sri Lanka (CBSL), Annual Report 2019.

Cervellati, M., \& Sunde, U. (2011). Life Expectancy and Economic Growth: The Role of the Demographic Transition. Journal of economic growth, 16(2), 99-133.

Checherita, C., \& Rother, P. (2010). The impact of high and growing government debt on growth: an empirical investigation for the Euro area (No. 1237). ECB Working paper.

Chowdhury, A. (2001). External debt and growth in developing countries: a sensitivity and causal analysis. WIDER-Discussion Papers.

Chowdhury, K. (1994). Structural analysis of external debt and economic growth: some evidence from selected countries in Asia and the Pacific. Applied Economics, 26, 1121-1131

Cohen, D. (1993). Low Investment and Large LDC Debt in the 1980s American Economic Review, 83(3), 437-49.

Eberhardt, M., \& Presbitero, A. F. (2015). Public debt and growth: Heterogeneity and non-linearity. Journal of International Economics, 97(1), 45-58.

Ekanayake, D. G. D. I. (2011). Assessing government debt sustainability in Sri Lanka. Retrieved, 10(14), 2013.

Fonseka, A. T., \& Ranasinghe, S. S. (2007). Sustainability of Sri Lanka's public debt. Sri Lankan Journal of Management, 12(3\&4), 185-212.

Geiger, L. T. (1990). Debt and economic development in Latin America. The Journal of Developing Areas, 24(2), 181-194.

Granger, C. W., Newbold, P., \& Econom, J. (1974). Spurious regressions in econometrics. Baltagi, Badi H. A Companion of Theoretical Econometrics, 557-61

Jha, R., \& Schatan, C. (2001). Debt for Nature: A swap whose time has gone?. Available at SSRN 243755

Kappagoda, N. (2004). Public debt: institutional issues. S. Kelegama, Economic Policy in Sri Lanka: Issues and Debates, 153-176.

Khalil Jebran, A. A., Hayat, U., \& Iqbal, A. Public debt and economic growth in Pakistan: a Reassessment.

Kumar, M., \& Woo, J. (2010). Public debt and growth. IMF working papers, 1-47.

Kumara, H., \& Cooray, N. S. (2013). Public Debt and Economic Growth in Sri Lanka: Is There Any Threshold Level for Pubic Debt. Economics \& Management Series, EMS-2013-22). Minamiuonuma: IUJ Research Institute, International University of Japan.

Lee, S. P., \& Ng, Y. L. (2015). Public debt and economic growth in Malaysia. Asian Economic and Financial Review, 5(1), 119-126.

Moki, M. (2012). An analysis of the relationship between public debt and economic growth in Africa. Unpublished MBA Project, University of Nairobi. 
Ntshakala, P. L. (2015). Effects of public debt on economic growth in Swaziland. International Journal of Business and Commerce, 5(1), 1 24.

Obademi, O. E. (2012). An empirical analysis of the impact of public debt on economic growth. Canadian Journal of Social Sciences, 8(4), 154 161.

Panizza, U. (2009). Domestic and External Public Debt in Developing Countries, preliminary unpublished version.

Panizza, U., \& Presbitero, A. F. (2013, January). Public Debt and Economic Growth in Advanced Economies. Working paper (78), 1-24.

Panizza, U., \& Presbitero, A. F. (2014). Public debt and economic growth: is there a causal effect?. Journal of Macroeconomics, 41, 21-41.

Rais, S. I., \& Anwar, T. (2012). Public debt and economic growth in Pakistan: A time series analysis from 1972 to 2010 . Academic research international, 2(1), 535

Rueff, J. (1929). Mr. Keynes' views on the transfer problem. The Economic Journal, 39(155), 388-399.

Sachs, J. D., \& Warner, A. M. (1995). Natural resource abundance and economic growth (No. w5398). National Bureau of Economic Research.

Safdari, M., \& Mehrizi, M. A. (2011). External debt and economic growth in Iran. Journal of economics and international finance, 3(5), 322-327.

Schclarek, A. (2005). Debt and economic growth in developing and industrial countries. Department of Economics, Lund University.

Shah, M., \& Pervin, S. (2012). External public debt and economic growth: empirical evidence from Bangladesh, 1974 to 2010. Academic Research International, 3(2). Pages

Sheikh, M. R., Faridi, M. Z., \& Tariq, K. (2010). Domestic Debt and Economic Growth in Pakistan: An Empirical Analysis. Pakistan Journal of Social Sciences (PJSS), 30(2), 373-387.

Smyth, D. J., \& Hsing, Y. (1995). In search of an optimal debt ratio for economic growth. Contemporary Economic Policy, 13(4), 51-59.

Stylianou, T. (2014). Debt and economic growth: Is there any causal effect? An empirical analysis with structural breaks and Granger causality for Greece. Theoretical and Applied Economics, 21(1), 51-62.

Wijeweera, A., Dollery, B., \& Pathberiya, P. (2005). Economic growth and external debt servicing: a cointegration analysis of Sri Lanka, 1952 to 2002. The University of New England working paper series in economics, 8.

Yeasmin, F., Chowdhury, M. N. M., \& Hossain, M. A. (2015). External Public Debt and Economic Growth in Bangladesh: A Co-Integration Analysis. civilization, 6(23), 64-74. 
